prices of necessary staples, like coal, lumber, cord wood and kerosene (which was coming into more general use in the 60's). Mixed with this useful information are facts, quotations and opinions on any subject which interested Mr. Noyes.

The chief impression that one gets from the memorandum books is of the personality of Mr. Noyes - a keen Vermont Yankee trader, ready to make a profit no matter how small, either from junk or a house lot, minding his own business with considerable energy, and yet with ample time to mind the business of those with whom he came in contact or who had attracted his attention. Such knowledge might be of great value to him in the numerous applications to him for loans. It appears in one of the books that the population of Burlington had doubled between 1860 and 1870 and the prosperity of Mr. Noyes seems to have gone along with that growth and with the extension of his unique business as Master Peddler.

\title{
Proposed Legislation for the Fashions of the 50's
}

Among the heterogeneous mass of Baldwin engineering papers which have just arrived in Baker Library - and will be discussed in the next issue of the Bulletin - there is a copy of a Canadian bill which was introduced in 1859. It describes itself as "An Act for the Reform and Regulation of Female Apparel, and to amend and reform the Customs relating to Crinoline and other Artificial Superfluities and the Profusion thereof," with powers, fines, forfeitures and penalties to be exercised for enforcement.

The preamble explains that, "whereas evidence hath been produced, and it hath been shown, to the satisfaction of this Honorable House, that in the year of Grace one thousand eight hundred and fifty-nine the Ladies of this Province have degenerated in their ideas of beauty and propriety; have deserted the wise and modest apparel of their ancestors, and adapted in lieu thereof the flowing and elaborate Skirts, supported and sustained in their amplitude by certain contrivances of Springs, Ladders, Hinges, \&c., and a certain other Apparatus known by the name of Crinoline, and the gaudy and expensive Trimmings, Fashions and Appurtenances which evil and designing persons-have introduced into this country from a neighboring Republic, whose people in the excess of their unbridled 
sarcasm, have been in the habit of stigmatising Her Majesty's Loyal Subjects in this Province as 'Tarnal Britishers,' " some regulation of these abominable fashions is necessary for the "clearing of the Public Thoroughfares, for the protection of Her Majesty's Subjects in general, and for divers other cogent reasons quite unnecessary to mention."

Wherefore Her Majesty will order on the date of passage of the bill that no female shall "appear in any Publick Street, Way, Thoroughfare or Path, nor be or appear in any Church, Theatre, Doorway, Railroad, Private Carriage, Steamboat, Ballroom, or in any Private Apartments, dressed or enveloped in any artistically formed framework which shall be of the diameter of two yards or upwards, whether the same be fashioned out of Steel, Whalebone, Cord, Whickerwork, India-rubber, Gutta-percha, or any other material, and whether or not the same be screwed together or fitted with hinges or other apparatus to render the same collapsible or contractible."

These stringent measures even increase and the third article of the bill states that, "No female above the age of forty shall wear, deck, or bedizen herself in any Underskirt or Petticoat, the pattern of which shall be red and black striped, tub or barrel pattern, or any other pattern approaching to chess or draught-board pattern, or any other pattern or color which shall be likely to cause the taking fright of any horse, ox, or ass, or shall be calculated to cause the unnecessary barking of puppies, or draw forth the precocious remarks of any small boys or girls of the present generation who may espy the same, although the same remarks may be gratuitously delivered."

In the case of a married woman under fifty years of age, a pattern or piece of the material "shall be submitted to the husband for approval within two days after the same shall have been so obtained, and the husband shall signify his approval of such pattern by a certificate in writing."

It is ordered that any "Frames, Skeletons, Gratings, or Wickerwork, or other Machinery" still in good condition shall be used as "Fireguards, Door Mats, Bird Cages or Clothes' Bags ... and the Petticoats or Underskirts may be devoted to Agricultural purposes by tearing the same into Ribbons for the scaring of Birds, or presented to the Royal Canadian. Club for flags."

Similarly boots are taken into consideration with a full prohibition of "Black Boots with pink red or green binding" and those 
which "for color or configuration, shall draw attention to the large size or expressively elegantly shaped foot of the wearer."

Bonnets receive a full paragraph and it is stipulated that none shall be "more than ten inches off the forehead or pinned on to the back hair, or the curtain of which shall sit or rest on the back of the neck, or shall be fastened on by steel springs or otherwise, so as to sit entirely behind the ears."

Article IX is the only affirmative statement in the bill and generously permits that "any female of common sense and discretion, properly accomplished, and of an average standard of beauty, may wear under certain restrictions (to be determined by herself) Hairy Dogskin Cloaks, Bearskin Mantles, or embroidered Petticoats (if the actual work of the wearer), or ugly Sunshades, Pinkstays, Colored Stockings, or Garters, or Gauntlet Gloves."

Whether the parliamentary discussions of 1859 were bitter with predictions of the inescapable consequences of such legislation is not known, but one suspects that Canada, having reason to fear an uprising among 50 per cent of its population, was loath to take such drastic measures even for the public welfare.

\section{Secretary's Column}

\section{AcQuisitions}

During the few weeks which have elapsed since the publication of the last Bulletin, the Society has received and gratefully acknowledges the following acquisitions:

From Price Waterhouse and Company, New York City.

Four cases of miscellaneous statistical data.

From Richard Peters, Jr., Philadelphia.

Papers of the Tecumseh Iron Company, including Sales Records of I 878 and Bills of Lading; also, Time Tables of the New York and New England Railroad, I876, and of the East Tennessee, Virginia and Georgia Railway System of 1890 .

From Charles E. Rogerson, President, Boston Safe Deposit and Trust Co., Boston.

Trust agreement for construction of Alabama and Chattanooga Railroad, i 869.

Protest of Citizens' Association of Boston, 1898.

Reports of Franklin Savings Bank, Boston, 1912.

Reports relating to development of Hamilton Mfg. Co., Boston, I884 and 1924. 